\title{
HTLV-1 and HIV infections of the central nervous system in tropical areas
}

\author{
P Cabre, D Smadja, A Cabié, C R J C Newton
}

\section{Department of \\ Neurology, University \\ Hospital of \\ Fort-de-France, \\ Martinique, French \\ West Indies \\ P Cabre \\ D Smadja \\ Department of \\ Internal Medicine, \\ University Hospital of \\ Fort-de-France, \\ Martinique, French \\ West Indies \\ A Cabié}

Neuroscience Unit, Institute of Child

Health, London, UK

C R J C Newton

Correspondence to: Dr D Smadja, Neurology Department, University Hospital of Fort-de-France, BP 632, 97261

Fort-de-France Cedex,

Martinique, French West

Indies

Received 2 August 1999 Accepted 7 September 1999
In tropical areas, the human $\mathrm{T}$ lymphotropic virus type 1 (HTLV-1) infection is often superimposed on the human immunodeficiency virus (HIV) endemic. However, from a clinical point of view, the neurological consequences of HTLV-1 infection are not as prevalent as those of HIV infection. Only $0.25 \%$ of the HTLV-1 carriers develop a progressive myelopathy. ${ }^{1} \mathrm{By}$ contrast, CNS complications of HIV infection are frequent and often lethal. Most $(89 \%)$ of the 30.6 million HIV infected people are estimated to live in sub-Saharan Africa and developing countries of Asia, ${ }^{2}$ but the neurological complications have been well described in other populations. By contrast, HTLV-1 infection is mostly confined to tropical areas. This review highlights the differences in the neurological complications of HIV infection, and the management of these complications in tropical countries from other parts of the world, and discusses HTLV-1 infections.

\section{HIV infection}

Neurological disorders complicate HIV infection in $30 \%$ to $40 \%$ of patients, and any part of the neuraxis may be affected. ${ }^{34}$ Furthermore, some studies have shown neuropathological abnormalities in $75 \%$ to $90 \%$ of patients dying with AIDS. ${ }^{35-7}$ In tropical countries CNS abnormalities are also frequent in clinical and postmortem studies. ${ }^{6-14}$ Early CNS infection is usually asymptomatic or responsible for rare disorders such as acute aseptic meningitis or encephalitis. ${ }^{1516}$ During the later stages of infection both the major CNS opportunistic infections and AIDS dementia complex develop. ${ }^{4}{ }^{17}$ Since 1996 , the use of highly active antiretroviral therapy has decreased morbidity and mortality in HIV infected patients with advanced disease. ${ }^{18}{ }^{19}$ Incidence rates of neurological manifestations such as HIV associated neuropsychological impairment and opportunistic infections seem to have declined. ${ }^{20-22}$ Unfortunately, in most tropical countries, antiretroviral therapy is not available and diagnostic tools are often limited. Although difficult to determine, the prevalence of neurological complications in tropical countries seems different compared with occidental countries. ${ }^{7111723}$ Thus HIV infections in tropical countries could kill patients before the other neurological manifestations have the time to develop. In these countries, three treatable opportunistic infections - namely, cryptococcal meningitis, toxoplasmosis, and tuberculosis (table 1) cause most of the morbidity and mortality. ${ }^{4-12}{ }^{23-31}$ The different profile of neurological manifestations between tropical and industrialised countries could reflect local geographical or socioeconomic conditions and variation in risk factors. ${ }^{7117}$

\section{CRYPTOCOCCAL MENINGITIS (CM)}

Cryptococcal meningitis is the most common life threatening fungal opportunistic infection in HIV infected patients. ${ }^{32}$ The estimated incidence of $\mathrm{CM}$ in these patients varies between $5 \%$ and $10 \%$ in the United States and 30\% in tropical countries such as sub-Saharan Africa, Asia, and South and Central America. ${ }^{6-9112325-283132}$ In Zimbabwe, CM accounts for $45 \%$ of all laboratory proved

Table 1 Central nervous system complications of patients infected with HIV

\begin{tabular}{|c|c|c|c|c|c|c|}
\hline \multirow[b]{2}{*}{ Countries } & \multicolumn{3}{|c|}{ Necropsy series } & \multicolumn{3}{|l|}{ Clinical series } \\
\hline & France $^{5}$ & India $^{11}$ & $\mathrm{Brazil}^{7}$ & Côte d'Ivoire ${ }^{12}$ & Mexico $^{23}$ & $U S A^{23}$ \\
\hline Number of patients & 148 & 67 & 230 & 42 & 40 & 130 \\
\hline Period of study & $1982-1988$ & 1988-1996 & $1985-1990$ & 1995 & $1986-1988$ & $1986-1988$ \\
\hline \multicolumn{7}{|l|}{ Focal disorders } \\
\hline Cerebral toxoplasmosis & $44 \%$ & $16 \%$ & $34 \%$ & $36 \%$ & $7.5 \%$ & $4.6 \%$ \\
\hline Primary lymphoma & $11 \%$ & 0 & $4 \%$ & 0 & $2.5 \%$ & $8.4 \%$ \\
\hline Progressive multifocal leucoencephalopathy & $3 \%$ & 0 & 0 & 0 & $2.5 \%$ & $3.8 \%$ \\
\hline \multicolumn{7}{|l|}{ Non-focal diseases } \\
\hline Cytomegalovirus encephalitis & $17 \%$ & $9 \%$ & $7.9 \%$ & 0 & 0 & $18.5 \%$ \\
\hline \multicolumn{7}{|l|}{ Meningitis } \\
\hline Cryptococcal meningitis & $1 \%$ & $10 \%$ & $13.5 \%$ & $12 \%$ & $17.5 \%$ & $13 \%$ \\
\hline Tuberculosis & $0.6 \%$ & $15 \%$ & 0 & $7 \%$ & $10 \%$ & $1 \%$ \\
\hline Aseptic meningitis & NA & NA & NA & $0 \%$ & $7.5 \%$ & $6.1 \%$ \\
\hline Bacterial meningitidis & NA & NA & NA & $12 \% \%$ & 0 & 0 \\
\hline
\end{tabular}

$\mathrm{NA}=$ not available 
cases of meningitis in adults. ${ }^{24}$ The high rate of cryptococcal infection in tropical countries seems to be due to the usual presence of Cryptococcus neoformans in the environment of patients with AIDS. ${ }^{33}$ Although unusual $(25 \%$ to $30 \%$ of patients), meningeal symptoms may be seen with $\mathrm{CM}^{32}$ If available, the latex agglutination test for cryptococcal antigen detection in both serum and CSF is a highly sensitive and specific procedure in the diagnosis of cryptococcosis and can be used as a screening tool in febrile patients. ${ }^{32}$ Despite treatment, mortality in the acute stage of CM remains high $(10 \%-25 \%)$ and the 1 year survival rate is about $30 \%-60 \% .{ }^{33-35}$ In Malawi, the median survival was 4 days without treatment after CM had been diagnosed. ${ }^{28}$ In a prospective study from Zimbabwe focusing on natural history of $\mathrm{CM}$, the cumulative median survival was 14 days ( 0 to 233 days) and the 1 month survival rate was $22 \%{ }^{24}$ Thus, many patients seem to have an indolent course even without treatment. The treatment consists of intravenous amphotericin B $(0.7 \mathrm{mg} / \mathrm{kg} /$ day $) .^{33}$ Cost, need for parenteral administration, and toxicity are the main limitations of use of amphotericin B. Fluconazole has shown similar rates of treatment success to those of low doses $(0.4 \mathrm{mg} / \mathrm{kg} / \mathrm{day})$ of intravenous amphotericin B. ${ }^{34}$ However, in America the 2 week mortality was higher in the fluconazole group than in the amphotericin B group (15\% v 8\%). The current recommendation for treatment of $\mathrm{CM}$ is to use amphotericin B $(0.7 \mathrm{mg} / \mathrm{kg} /$ day $)$ and flucytosine $\left(25 \mathrm{mg} / \mathrm{kg}\right.$ four times daily). ${ }^{36}$ After 2 weeks, this combination may be supplanted by oral fluconazole $(400 \mathrm{mg} /$ day) for 8 weeks (table 2). This therapy seems very successful $(6 \%$ of initial mortality and $8 \%$ of overall mortality). ${ }^{36}$ Lifelong maintenance therapy is essential to prevent relapse of $\mathrm{CM} .^{32}$ Fluconazole (200 mg daily) has now been shown to be more effective and better tolerated than amphotericin B and is the preferred agent for secondary prophylaxis. $^{37}$ Unfortunately, in many tropical countries, this antifungal treatment is not available. These antifungal agents were not included in the list of essential drugs needed in Zimbabwe. ${ }^{24}$ Cost of the induction phase of therapy for CM amounts to several times the average monthly salary in Zimbabwe and in many resource poor sub-Saharan African countries. ${ }^{24}$ Easily managed and cost effective treatments are absolutely necessary for CM in developing countries. A comparative 2 month study of fluconazole (200 mg/day) with flucytosine $(150 \mathrm{mg} / \mathrm{kg} /$ day) for the first 2 weeks with fluconazole alone at the same dose in 58 Ugandan patients showed a lower initial mortality in the combination group $(16 \% v$ $40 \%){ }^{29}$ After 4 months of maintenance therapy (fluconazole at $200 \mathrm{mg}$ three times weekly), survival rate was higher in the combination group ( $32 \% v 12 \%)$.

TOXOPLASMOSIS ENCEPHALITIS (TE)

Toxoplasmosis encephalitis is the most common opportunistic infection causing encephalitis or focal cerebral lesions. ${ }^{38}$ About 3\% to $40 \%$ of patients with AIDS will develop TE (table 1). ${ }^{38}{ }^{39}$ In tropical countries, the frequency of TE in necropsy series of AIDS patients is high: $34 \%$ in Brazil, ${ }^{7} 23 \%$ in Côte d'Ivoire, ${ }^{30}$ and $19 \%$ in India. ${ }^{11}$ Risks factors for TE are a previous Toxoplasma gondii infection and a CD4+ cell count $<100 / \mathrm{mm}^{3}$. ${ }^{40}$ Geographical differences in TE rates among patients with AIDS may be explained by the worldwide observed variation of Toxoplasma IgG seroprevalence. ${ }^{40}$ TE presents with a constellation of symptoms and signs, of which only chorea is thought to be pathognomonic in patients with AIDS. ${ }^{38}$ Diagnosis is made on the basis of clinical symptoms and CT or MRI findings (contrast enhancing space occupying lesions of the brain). ${ }^{38}$ In tropical countries where CT is not available, the diagnosis should be made on clinical grounds and fast response to presumptive therapy.

The current recommended therapy of TE is a 4 to 8 week course of sulfadiazine and pyrimethamine. ${ }^{3841}$ Adverse reactions to these medications are common, occurring in as many as $25 \%$ to $53 \%$ of patients. ${ }^{38}$ Alternative less toxic medications - namely, azithromycin, clarithromycin, atovaquone, and trimethoprimsulfamethoxazole (TMP-SMZ) - are under investigation. ${ }^{42-44}$ In an open study, we have followed up 21 patients who were treated with TMP-SMZ (160 mg trimethoprim and $800 \mathrm{mg}$ sulfamethoxazole three times daily by oral or

Table 2 Treatment and prophylaxis of cryptoccocosis and toxoplasmosis in HIV infection

\begin{tabular}{|c|c|c|}
\hline & First choice & Alternative \\
\hline \multicolumn{3}{|l|}{ Cryptoccocosis } \\
\hline Acute infection & $\begin{array}{l}\text { Amphotericine B, } 0.7 \mathrm{mg} /(\mathrm{kg} \text {.day) iv and flucytosine, } 100 \\
\mathrm{mg} /(\mathrm{kg} \text {.day) orally or iv in } 4 \text { divided doses for } 2 \text { weeks, then } \\
\text { fluconazole, } 400 \mathrm{mg} \text { orally four times daily for } 8 \text { weeks }\end{array}$ & $\begin{array}{l}\text { Fluconazole, } 400 \mathrm{mg} \text { orally four times daily for } 10 \text { weeks, or } \\
\text { Fluconazole } 200-400 \mathrm{mg} \text { orally four times daily for } 10 \text { weeks } \\
\text { and flucytosine } 150 \mathrm{mg} /(\mathrm{kg} \text {.day) orally or iv in } 4 \text { divided doses } \\
\text { for } 2 \text { weeks }\end{array}$ \\
\hline Suppressive therapy & Fluconazole $200 \mathrm{mg}$ orally four times daily & $\begin{array}{l}\text { Amphotericine } \mathrm{B}, 0.6-1.0 \mathrm{mg} / \mathrm{kg} \text { iv four times weekly, or } \\
\text { Itraconazole, } 200 \mathrm{mg} \text { orally four times daily }\end{array}$ \\
\hline \multicolumn{3}{|r|}{ 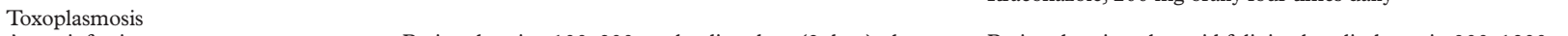 } \\
\hline Acute infection & $\begin{array}{l}\text { Pyrimethamine } 100-200 \mathrm{mg} \text { loading dose }(2 \text { days), then } \\
50-100 \mathrm{mg} \text { orally four times daily plus folinic acid } 10 \mathrm{mg} \\
\text { orally four times daily+ sulfadiazine } 4-8 \mathrm{~g} \text { orally four times } \\
\text { daily for at least } 6 \text { weeks }\end{array}$ & $\begin{array}{l}\text { Pyrimethamine plus acid folinic plus clindamycin } 900-1200 \\
\text { mg iv four times } / 6 \mathrm{~h} \text { or } 300-450 \mathrm{mg} \text { orally four times } / 6 \mathrm{~h} \text { for at } \\
\text { least } 6 \text { weeks, or } \\
\text { Trimethoprim, } 160 \mathrm{mg} \text { plus sulfamethoxazole, } 800 \mathrm{mg} / 8 \mathrm{~h} \\
\text { orally or iv for at least } 6 \text { weeks }\end{array}$ \\
\hline Suppressive therapy & $\begin{array}{l}\text { Pyrimethamine } 25-75 \mathrm{mg} \text { orally four times daily plus folinic } \\
\text { acid } 10 \mathrm{mg} \text { orally four times daily }+ \text { sulfadiazine } 500-1000 \\
\mathrm{mg} \text { orally four times } / 6 \mathrm{~h}\end{array}$ & $\begin{array}{l}\text { Pyrimethamine plus acid folinic plus clindamycin } 300-450 \mathrm{mg} \\
\text { orally four times/ } 6 \mathrm{~h} \text {, or } \\
\text { Trimethoprim, } 160 \mathrm{mg} \text { plus sulfamethoxazole, } 800 \mathrm{mg} \text { orally } \\
\text { four times daily }\end{array}$ \\
\hline $\begin{array}{l}\text { Prophylaxis (patients with positive IgG } \\
\text { serology and CD } 4 \text { count }<100 / \mathrm{mm}^{3} \text { ) }\end{array}$ & $\begin{array}{l}\text { Trimethoprim, } 160 \mathrm{mg} \text { plus sulfamethoxazole, } 800 \mathrm{mg} \\
\text { orally four times daily }\end{array}$ & $\begin{array}{l}\text { Dapsone } 50 \mathrm{mg} / \text { day plus pyrimethamine } 50 \mathrm{mg} / \text { week plus } \\
\text { folinic acid } 25 \mathrm{mg} / \text { week }\end{array}$ \\
\hline
\end{tabular}


intravenous route for 4 to 6 weeks). ${ }^{44}$ Clinical and radiological improvements were achieved in $94 \%$ of patients. Severe toxicity leading to alternative treatment occurred in two patients. Considering large availibility, good tolerance, easy management, and low cost, TMP-SMZ seems a treatment of choice for $\mathrm{TE}$ in tropical countries. ${ }^{31}$

TUBERCULOSIS (TB)

One third of the world's population is thought to be infected with Mycobacterium tuberculosis. ${ }^{45}$ In 1990, the WHO estimated that active disease occurs in 8 to 10 million people and that 3 million people died of TB each year. ${ }^{45}$ HIV infection is the strongest risk factor for the progression of latent $M$ tuberculosis infection to active TB. $^{46}$ By mid-1995, nearly 7 million people worldwide were estimated to be coinfected with $M$ tuberculosis and HIV, of whom 4 million live in Africa, 3 million in south and south east Asia, and 0.4 million in Latin America and the Caribbean basin. ${ }^{47} 48$ TB is a major cause of death in patients infected with HIV worldwide. In Abidjan (Côte d'Ivoire) TB was seen in $54 \%$ of AIDS cadavers. ${ }^{30}$ In sub-Saharan African countries, in which the rates of HIV infection are the highest, the incidence of TB has more than doubled since the early 1980s. ${ }^{47}{ }^{48}$ In Asia, the expanded HIV epidemic has led to occurrence of new cases of TB attributable to HIV, with the same magnitude as in sub-Saharan Africa. ${ }^{47}$ In North American or European studies, CNS TB is unusual and occurs in $5 \%$ to $10 \%$ of patients infected with HIV. ${ }^{48-50}$ HIV infection does not seem to alter the clinical and laboratory manifestations or the prognosis of TB meningitis. By contrast with non-HIV infected patients, CNS mass lesions, including cerebral abscesses and tuberculomas, are more often demonstrated by CT or MRI in patients with AIDS. ${ }^{51}$ In tropical countries, TB meningitis is a relatively frequent complication of HIV infection, and such infection is often undiagnosed (table 1). Despite antituberculous drugs, the mortality of TB meningitis remains high. ${ }^{51}$ In resource poor tropical countries, antituberculous regimens containing rifampin are often unavailable.

\section{AIDS-DEMENTIA COMPLEX (ADC)}

AIDS-dementia complex is an HIV specific syndrome of subcortical dementia characterised by slowness and imprecision of cognition and motor control. ${ }^{4}$ The earliest symptoms of ADC are cognitive and patients complain of difficulties in concentration and forgetfulness; and relatives notice difficulties in thinking. Later, diffuse motor abnormalities include ataxia, hyperreflexia, and the appearance of frontal lobe release reflexes such a snout response, are present with possible progression to tetraparesis. ADC is often associated with a vacuolar myelopathy (ataxia, spastic paraparesia, hyperreflexia, and incontinence).

ADC develops mainly in patients with severe immunosuppression. In the United States the incidence rate of ADC over a 5 year period is 7.3 cases per 100 person-years for people with
CD4 counts of 100 or less. ${ }^{4}$ In Kinshasa, the estimated prevalence of ADC was $8.7 \%$ in a cross sectional study of HIV infected patients admitted to hospital. ${ }^{6}$ Antiretroviral therapy can only improve ADC symptoms. ${ }^{4}$

\section{NEUROMUSCULAR DISORDERS}

Neuromuscular disorders are common and important causes of morbidity. ${ }^{4}$ Autoimmune demyelinating neuropathies or inflammatory myopathy usually develops in the early stage of HIV infection. The prognosis is good with corticosteroid therapy. By contrast, during the late stage of HIV infection, CMV polyradiculopathy, CMV mononeuritis multiplex, or HIV polyneuropathy distal, axonal and predominantly sensory are associated with a poor prognosis. There are few data on the frequency of these manifestation in tropical countries.

\section{HIV INFECTION IN CHILDREN}

HIV infection of children is rapidly increasing, with more than 1600 children becoming infected each day. Most of these infections occur in sub-Saharan Africa, where over 22 million children are infected with HIV. Most children acquire HIV from their mothers, particularly during labour, but also during pregnancy, and the postnatal period from breast milk. Blood transfusion for the treatment of severe anaemia and malaria is another important source in developing countries. ${ }^{52}$

HIV readily infects the developing CNS of children, and is a major cause of morbidity and contributes to the fatal outcome..$^{53}$ Postmortem studies show that most children dying with AIDS have evidence of neurological involvement. ${ }^{54}$ Children more often have a HIV encephalitis, and less superimposed infections and lymphoma than adults, ${ }^{55}$ particularly children living in tropical countries. ${ }^{56}$

HIV infection of the CNS usually manifests after other clinical features of HIV infection. The most common manifestations in Europe and North America are delayed development, loss of developmental milestones, cerebral atrophy, and pyramidal tract signs. The progressive encephalopathy (with loss of milestones and cerebral atrophy) usually occurs before the age of 3 years, and is associated with a high viral load and early decrease in CD4 lymphocytes. ${ }^{57}$ Other neurological manifestations include stroke, ${ }^{58}$ extrapyramidal, ${ }^{59}$ and cerebellar signs, and peripheral neuropathies. ${ }^{60}$

In Africa, perinatal HIV infection is associated with motor and cognitive delay. ${ }^{61}$ In birth cohort studies from Rwanda and Uganda, abnormal neurological signs were elicited in $15 \%-40 \%$ of $\mathrm{HIV}$ infected children during the first 2 years of life. ${ }^{62}$ Most of these children have developmental delay, with a reduction in the growth of the head circumference, suggesting cerebral atrophy. Studies from Rwanda suggest that progressive encephalopathy is relatively rare. $^{63}$

\section{HTLV-1 infection}

In 1964, a progressive thoracic myelopathy was described in Jamaican adults and this disorder was termed tropical spastic paraparesis 
Table 3 Symptoms and signs of HAM/TSP

\begin{tabular}{|c|c|c|c|}
\hline & $\begin{array}{l}\text { Vernant et al } \\
n=25\end{array}$ & $\begin{array}{l}\text { Araujo et } \text { al }^{73} \\
n=34\end{array}$ & $\begin{array}{l}\text { Bhigjee et } a l^{74} \\
n=24\end{array}$ \\
\hline Race & Afro-Caribbean & Mainly white & Bantu \\
\hline Mean duration & 8 years & 7 years & Less than 1 year \\
\hline \multicolumn{4}{|l|}{ Symptoms (\%): } \\
\hline Leg weakness & 100 & 97 & 100 \\
\hline Backache & 28 & 44 & 49 \\
\hline Painful legs & 40 & Occasional & Unknown \\
\hline Paraesthesias & 44 & 21 & 45 \\
\hline Urinary frequency or incontinence & 96 & 94 & 78 \\
\hline \multicolumn{4}{|l|}{ Signs (\%): } \\
\hline Leg spasticity & 100 & 88 & 100 \\
\hline Arm spasticity & 92 & 18 & 82 \\
\hline Inability to walk & 44 & 9 & 50 \\
\hline Ability to walk & 56 & 91 & 50 \\
\hline Sensory level & 4 & 14 & 49 \\
\hline Abnormal superficial sens. & 40 & 27 & 53 \\
\hline Abnormal deep sensitivity & 28 & 62 & 49 \\
\hline
\end{tabular}

(TSP).$^{64}$ In 1985, Gessain et al clarified the aetiology of TSP by reporting in Martinique that $60 \%$ of these patients had antibodies to HTLV-1. ${ }^{65}$ In 1986, a similar myelopathy associated with HTLV-1 antibodies in the serum and CSF of Japanese patients was named HAM (HTLV-1-associated myelopathy) by Osame et al. ${ }^{66}$ These were the same disease, ultimately labelled HAM/TSP.

CAUSATIVE ORGANISM

HTLV-1 is a type C retrovirus sharing some distinctive features with the bovine leukaemia virus (BLV) and the simian $\mathrm{T}$ cell leukaemia virus (STLV) ${ }^{67}$ It has two regulatory genes: the tax gene which is responsible for the activation of viral replication, and the rex gene which, conversly, inhibits replication. Molecular analysis of HTLV-1 strains from the known endemic areas have identified three different genotypes-namely, widespread cosmopolitan subtype (HTLV-1 subtype A), large central African genotype (HTLV-1 subtype B), and Melanesian subtype (HTLV-1 subtype C).

\section{EPIDEMIOLOGY}

In tropical areas, HTLV-1 infection is endemic near the equator. Caribbean basin ${ }^{68}$ Colombia, and equatorial Africa $^{69}$ were the first high frequency pockets to have been reported. Numerous epidemiological studies have shown that HTLV-1 is mainly transmitted from husband to wife and mother to child and that the risk for seroconversion of household contacts is low. Exposure to contaminated blood products is the third known source. HTLV-1 is, however, a mildly infective virus; the prevalence among insular groups (island of Tsushima) or Amerindian populations ${ }^{70}$ illustrate the importance of geographical or cultural isolation which seems to be required for its propagation. The average age of onset of HAM/TSP is about 40 years, but it may begin between the ages of 20 and 70 years, although rarely younger than 15 . Women are affected more often than men by about $1.5: 1$. Highest prevalence rates $(100 / 100000)$ are found in Tumaco and the Seychelles. Although some clusters have been reported in Zaire (prevalence 50/100 000), epidemiological data on the situation of HAM/TSP in Africa remain scarce. Factors determining the onset of HAM/TSP in some infected people are not yet clearly under- stood. Lack of correlation between seroprevalence rates and occurrence of HAM/TSP in different ethnic groups of the same country suggest that besides HTLV-1 infection, critical environmental or genetic cofactors are responsible for the disease. HAM/TSP was initially thought to affect only poor black people living in tropical countries. ${ }^{71}$ However, its predominance among white people in Brazil demonstrates that HAM/TSP develops regardless of race and socioeconomic status. A recent Jamaican case-control study showed that an early age of initial sexual intercourse and more than five lifetime sexual partners increase the risk of HAM/TSP. ${ }^{72}$ Finally, patients have developed seroconversion and HAM/TSP in as little as 6 months after transfusion with contaminated blood products.

\section{CLINICAL FEATURES}

The most common initial symptom in patients with HAM/TSP is either leg weakness or difficulty in walking (table 3). ${ }^{68} 73$ Other common symptoms are painful legs, paraesthesias, back pain, and bladder dysfunction. The most common neurological sign is a spastic paraparesis which is asymmetric in one third of patients. Frequency of loss of touch and pain sensation ranges from $27 \%$ to $53 \%$ of the patients in three major series. ${ }^{68} 7374$ HAM/TSP usually presents with an insidious course. However, the evolution of the disease is rapid and aggressive in South Africa ${ }^{74}$ and spontaneous improvement has been reported among patients with definite HAM/TSP. ${ }^{75}$ Whatever the course of $\mathrm{HAM} / \mathrm{TSP}$, the clinical impression is that the neurological disability becomes relatively stable a few years after onset. ${ }^{76}$ Some authors have noted a down beat nystagmus suggesting that the lesions in HAM/TSP are not limited to the spinal cord but extend to the brainstem. Optic neuropathy (15\%) was described among the original patients with HAM/TSP. ${ }^{64}$ There are, however, a few cases of somewhat atypical HAM/TSP during the course of which optic neuritis occurs, thereby suggesting the diagnosis of multiple sclerosis with fortuitous HTLV-1 infection. On the other hand, convincing epidemiological data have shown a positive association between HTLV-1 and facial nerve palsy $^{77}$ and chronic hypertrophic pachymeningitis, which may eventually explain multiple cranial nerve involvement seen in some HTLV-1 infected people. Polyneuropathy has been mentioned in the literature, but many reports lack complete clinical and neurophysiological information and it still remains premature to conclude that HTLV-1 is a causal agent in polyneuropathy. Polymyositis or anterior cell degeneration linked to HTLV-1 sometimes develop in the presence ${ }^{78}$ or in the absence of HAM/TSP. Finally, the coexistence of systemic symptoms including alveolitis, ${ }^{79}$ sicca syndrome, ${ }^{79}$ arthritis, and infective dermatitis are the striking features of HAM/TSP.

\section{LABORATORY FEATURES}

A common feature is the presence of atypical lymphocytes with convoluted nuclei (flower cells) in the blood of infected patients. ${ }^{81}$ Higher 
titre specific anti-HTLV-1 antibody is present in the serum of patients with HAM/TSP than in asymptomatic carriers. The CSF demonstrates an intrathecal IgG synthesis (sensitivity $95 \%$ ) and a high local synthesis of HTLV-1 antibodies (sensitivity $85 \%$ ) in patients with HAM/TSP. ${ }^{82}$ Most patients with HAM/TSP also show an intrathecal immune response against HTLV-1 synthetic peptides (especially against HTLV-1 env gp21 synthetic peptides) ${ }^{83}$ contrasting with a poor polyspecific one against common viruses as seen in multiple sclerosis. Lower limb somatosensory evoked potential (SEP) studies detect unilateral or bilateral sensory spinal cord lesions in many patients with HAM/TSP. ${ }^{84}$ The most useful neurophysiological parameter seems to be the central sensory conduction time, which correlates well with disability score ${ }^{84}$ Experience with brainstem auditory evoked potentials supports a supraspinal involvment in some HAM/TSP patients. Motor pathway analysis is consistent with pathology affecting mainly the thoracolumbar cord. Magnetic resonance imaging of the spinal cord shows some degree of atrophy at the level of lower thoracic cord. Brain MRI usually shows white matter lesions similar to those seen in multiple sclerosis ${ }^{85}$ Frequency of small deep and subcortical white matter, small infratentorial and large periventricular lesions is lower in HAM/TSP than in multiple sclerosis.

PATHOGENESIS OF HAM/TSP

Lesions in HAM/TSP invariably predominate in the pyramidal tracts of the middle and lower thoracic spinal cord. They consist of a severe demyelination, perivascular, and parenchymal mononuclear infiltrates ( $\mathrm{T}$ and $\mathrm{B}$ lymphocytes and macrophages), reactive astrocytosis, micro- glial proliferation, and loss of axons $.^{86} \mathrm{CD} 4+\mathrm{T}$ cells and CD8+T cells are present equally in the early stage of the disease whereas CD8+T cells predominate in the late stage. ${ }^{86}$ In situ polymerase chain reaction of HTLV-1 proviral DNA has shown CD4+T cells to be the likely preferential virus reservoir in the CNS. ${ }^{87}$ Others found HTLV-1 DNA in areas devoid of immune cell infiltration. ${ }^{88}$ Expression of major histocompatibility complex (MHC) class I and class II molecules is increased on both $\mathrm{T}$ cells and glial cells. Interferon (IFN) $-\gamma,{ }^{89}$ interleukin (IL)-6, IL-1, granolocyte-macrophage colony stimulating factor, tumour necrosis factor (TNF) $-\alpha$ negative, and TNF- $\alpha$ positive cells have been detected in the CSF of HAM/TSP patients. Cytokine expression in some spinal cord lesions is gradually down regulated and together with the duration of illness is correlated with the decrease of $\mathrm{CD} 4+/ \mathrm{CD} 8+\mathrm{T}$ cell ratio. ${ }^{90}$

The promoter of the disease remains, however, unclear. There are at least three mechanisms through which, either alone or in combination, HTLV-1 infection could result in spinal cord injury in very few $(0.25 \%)$ infected people (figure). The cytotoxic hypothesis proposes that resident cells infected by $\mathrm{CD} 4+\mathrm{T}$ cells could process viral proteins in immunogen peptides resulting in a specific attack by cytotoxic lymphocytes (CTL) and subsequent CNS damage. ${ }^{91}$ Supporting the cytotoxic hypothesis, Lehky et al found by in situ hybridisation HTLV-1 tax m-RNA in very few astrocytes, but not in infiltrating CD4 T cells in the spinal cord of patients with HAM/TSP. ${ }^{92}$ These results have been discussed by others. ${ }^{93}$ The autoimmune hypothesis predicts an attack of CNS cells by either reactive $\mathrm{T}$ cells cross reacting with a CNS

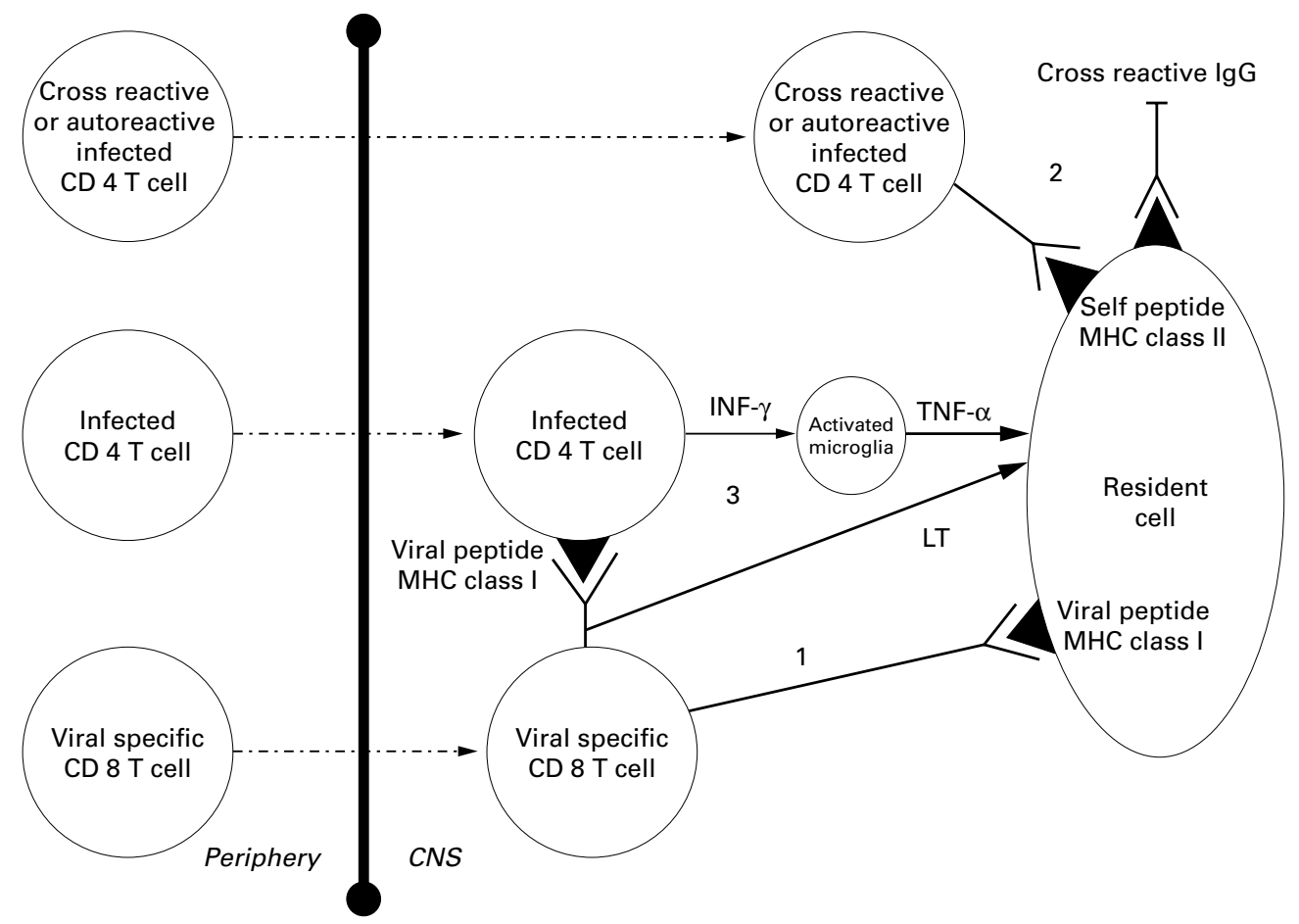

Pathogenesis of HAM/TSP. 1 =cytotoxic hypothesis; $2=$ autoimmune hypothesis; $3=$ bystander damage hypothesis; LT=lymphotoxin. 
antigen or CNS autoreactive CD4+T cells. Interestingly, the requirement of costimulatory molecules of the B7 family for autoreactivity is negated by HTLV-1 infection. ${ }^{94}$ The exact proportion of self reactive $T$ cells in the spinal cord lesions and the idenfication of the autoantigens involved in the autoimmune hypothesis require, however, further investigation. The bystander damage hypothesis speculates an immune reaction within the CNS without immune specificity for the CNS cells. Productively infected $\mathrm{CD} 4+\mathrm{T}$ cells would be the targets of the virally reactive CD8+T cells. ${ }^{95}$ Lesions of the CNS could result from myelinotoxic cytokines including TNF- $\alpha$ and lymphotoxin, respectively secreted by activated microglia and CD8+ T cells. The bystander damage hypothesis requires the presence of infected CD $4+T$ cells in the spinal cord, but this point remains a matter of controversy.

Recently, damage to the blood-brain barrier has been thought to be involved in the pathogenesis of HAM/TSP. Some findings suggest that VLA-4/VCAM-1 interaction may play a major role in mediating lymphocyte migration into the CNS. Matrix degrading metalloproteinases are a constant finding in CSF of patients with HAM/TSP. ${ }^{96}$ The host and viral factors that determine which infected people develop HAM/TSP are as yet poorly understood. There is to date no convincing data supporting specific HAM/TSP related mutations within the genome of the virus. By contrast, HLA haplotypes correlated with development of HAM/TSP in Japan and were associated with a high immune and intrathecal responsiveness against the virus. In addition, only the WKAH rat model of HAM/TSP emphasised the possible role of genetic host factors.

TREATMENT OF HAM/TSP

Based on the inflammatory nature of the CNS lesions in HAM/TSP, immunomodulatory agents were assessed in this disease. Some patients with HAM/TSP from Japan seemed to have a good response to steroid therapy, ${ }^{97}$ but the initial benefit disappeared with long term follow up, and has not been found in tropical areas. Clinical improvement under immunosuppressive agents such as azathioprine or cyclophosphamide was only marginal. ${ }^{98}$ Blood purification $^{98}$ or high doses of intravenous immunoglobulins provided no sustained clinical benefits. The dramatic efficacy of high dose vitamin $\mathrm{C}$ in a small open trial ${ }^{99}$ was not later confirmed. Five out of seven patients treated by IFN- $\alpha$ during the 22 week period of treatment, showed an improvement in motor performance which lasted up to 6 months. However, in another series of 43 patients, only $10(23.3 \%)$ improved by more than one grade in motor disability scale. ${ }^{98}$ Finally, antiretroviral drugs such as zidovidine were ineffective.

The presumed role in the pathogenesis of HAM/TSP of proinflammatory soluble mediators suggests new treatments. Inhibitors of TNF- $\alpha$ production may be beneficial. ${ }^{100}$ Also, therapeutic trials assessing inhibitor agents of MMPs or molecules involved in cell to cell adhesion could be conducted. However, considering the gradual decline of inflammatory lesions in the spinal cord of the affected patients, these potential agents must be assessed on a selected population in the early stage of HAM/TSP. In the late stage, only symptomatic therapies as physiotherapy or possibly intrathecal baclofen deserve consideration.

\section{Conclusion}

Although a definitive therapy is lacking for HAM/TSP, this disorder does not represent a major problem in tropical countries. In addition, a gradual decline in HTLV-1 seroprevalence and subsequent incidence of HAM/TSP can be expected in future, at least in some countries such as the French West Indies, with effective prevention. By contrast, HIV endemic is spreading in most of the developing countries, and neurological complications still remain a major world health problem. Inavailability of modern methods of diagnosis and treatment in HIV infected patients makes management of CNS manifestations in these areas a difficult challenge.

\section{Illustrative case}

A 52 year old black woman from Martinique West Indies presented with a 7 year history of slowly progressive weakness and stiffness in her legs as well as bladder dysfunction. Neurological examination showed a spastic paraparesis and extensor plantar responses. Western blot analysis identified antibodies to HTLV-1 in both serum and CSF. In the next year, January 1992, the patient noticed ocular and oral dryness. Although anti-SS-A and anti-SS-B antibodies were absent in serum, a positive Shirmer test and features of a biopsy specimen of the lip (Grade 4 Chisolm-Mason) were indicative of Sjögren's syndrome. In November 1992, she experienced proximal myalgia in the lower limbs, progressive dyspnoea, and blurring of vision. A biopsy specimen of the muscle was consistent with myositis. Dyspnoea at that time was related to a severe lymphocytic alveolitis, and the slit lamp study showed a bilateral anterior uveitis. Successive trials of prednisone (40 mg daily during 9 months) and cyclophosphamide (500 mg intravenously monthly during 6 months) resulted in a transient improvement of myositis, alveolitis, and uveitis. In February 1995, the patient was cachectic and paraparetic with evidence of both myelopathy and myositis. She had more difficulties in breathing and radiography of the chest evidenced a marked pulmonary fibrosis. She finally died from respiratory failure in March 1995.

1 Hollsberg P. Pathogenesis of chronic progressive myelopathy associated with human T-cell lymphotropic virus type 1 . Acta Neurol Scand 1997;(suppl 169):86-93.

2 Joint United Nations Programme on HIV/AIDS (UNAIDS) and World Health Organization. Global AIDS surveillance. Weekly Epidemiological Record 1997;72:357-60. 
3 Anders KH, Guerra WF, Tomiyasu V, et al. The neuropathology of AIDS. UCLA experience and review. $A m \mathcal{F}$ Pathol 1986;124:537-58.

4 Price WR. Neurological complications of HIV infection. Lancet 1996;348:445-52.

5 Matthiessen L, Marche C, Labrousse F, et al. Etude neuropathologique de l'encéphale de 174 patients mort du SIDA dans un hôpital parisien, de 1982 à 1988. Ann Med Interne 1992;143:43-9.

6 Perriens JH, Mussa M, Luabeya MK, et al. Neurological complication of HIV-1 seropositive internal medicine in patient in Kinshasa, Zaire. 7 Acquir Immune Defic Syndr patient in Kinshasa, Zaire. F

7 Chimelli L, Rosemberg S, Hahn MD, et al. Pathology of the central nervous system in patients infected with the human immunodeficiency virus (HIV): a report of 252 autopsy cases from Brazil. Neuropathol Appl Neurobiol 1992;18:47888.

8 Rosemberg S, Lopes MB, Tsanaclis AM. Neuropathology of acquired immunodeficiency syndrome (AIDS). Analysis of 22 Brazilian cases. F Neurol Sci 1986;76:187-98.

9 Santosh V, Shankar SK, Das S, et al. Pathological lesion in HIV positive patients. Indian f Med Res 1995;101:134-41.

10 Mohar A, Romo J, Salido F, et al. The spectrum of clinical and pathological manifestation of AIDS in a consecutive series of autopsied patients in Mexico. AIDS 1992;6:46773.

11 Lanjewar DN, Jain PP, Shetty CR. Profile of central nervous system pathology in patients with AIDS: an autopsy study from India. AIDS 1998;12:309-13.

12 Grant AD, Djomond G, Smets P, et al. Profound immunosuppression across the spectrum of opportunistic disease among hospitalized HIV-infected adults in Abidjan, Côte d'Ivoire. AIDS 1997;11:1357-64.

13 Howlet WP, Nkya WM, Mmuni KA, et al. Neurological disorders in AIDS and HIV in the northern zone of Tanzania. AIDS 1989;3:289-96.

14 Ramiandrisoa H, Dumas M, Giordano D, et al. Human retroviruses HTLV-1, HIV-1, HIV-2 and neurological diseases in West Africa. $\mathcal{F}$ Trop Geograph Neurol 1991;1:3944.

15 Kahn JO, Walker BD. Acute human immunodeficiency virus type 1 infection. N Engl f Med 1998;339:33-9.

16 Boufassa F, Bachmeyer C, Carré N, et al. Influence of neurologic manifestations of primary human immunodeficiency virus infection on disease progression. F Infect Dis $1995 ; 171: 1190-5$.

17 Levy RM, Janssen RS, Bush TJ, et al. Neuroepidemiology of acquired immunodeficiency syndrome. 7 Acquir Immune Defic Syndr Hum Retrovirol 1988;1:31-40.

18 Palella FJ, Delaney KM, Moorman AC, et al. Declining morbidity and mortality among patients with advanced human immunodeficiency virus infection. $N$ Engl $f \mathrm{Med}$ 1998;338:853-60.

19 Mouton Y, Alfandri S, Valette M, et al. Impact of protease inhibitors on AIDS-defining events and hospitalizations in 10 French AIDS reference centers. AIDS 1997;11:F101-5.

20 Power C, Nath A, Aoke F, et al. Remission of progressive multifocal leukoencephalopathy following splenectomy and antiretroviral therapy in a patients with HIV infection [letter]. N Engl f Med 1997;336:661-2.

21 Baqi M, Kucharczyk W, Walmsley SL. Regression of progressive multifocal encephalopathy with highly active antiretroviral therapy. AIDS 1997;11:1526-7.

22 Brodt HR, Kamps BS, Gute P, et al. Changing incidence of AIDS-defining illnesses in the era of antiretroviral combiAIDS-defining illnesses in the era of a
nation therapy. AIDS 1997;11:1731-8.

23 Trujillo JR, Garcia-Ramos G, Novak IS, et al. Neurologic manifestations of AIDS: a comparative study of two populations from Mexico and the United States. I Acquir Immune Defic Syndr Hum Retrovirol 1995;8:23-9.

24 Heyderman RS, Gangaidzo IT, Hakim JG, et al. Cryptococcal meningitis in human immunodeficiency virus-infected patients in Harare, Zimbabwe. Clin Infect Dis 1998;26:2849.

25 Imwidthaya P. One year's experience with Cryptococcus neoformans in Thailand. Trans R Soc Trop Med Hyg 1994;88: 208.

26 Khanna N, Chandramuki A, Desai A, et al. Cryptococcal infections of the central nervous system: an analysis of predisposing factors, laboratory findings and outcome in patients from South India with special reference to HIV infection. f Med Microbiol 1996;45:376-8.

27 Rozenbaum R, Goncalves AJR. Clinical epidemiological study of 171 cases of cryptococcosis. Clin Infect Dis 1994;18:369-80.

28 Maher D, Mwandumba H. Cryptococcal meningitis in Lilongwe and Blantyre, Malawi. F Infect 1994;28:59-64.

29 Mayanja-Kizza H, Oishi K, Mitarai S, et al. Combination therapy with fluconazole and flucytosine for cryptococcal meningitis in Ugandan patients with AIDS. Clin Infect Dis 1998;26:1362-6.

30 Lucas SB, Hounnou A, Peacock C, et al. The mortality and pathology of HIV infection in a west African city. AIDS 1993;7:1569-79.

31 Kaplan JE, Hu DJ, Holmes KK, et al. Preventing opportunistic infections in human immunodeficiency virus-infected persons: implications for the developing world. Am 7 Trop Med Hyg 1996;55:1-11.

32 Powderly WG. Cryptococcal meningitis and AIDS. Clin Infect Dis 1993;17:837-42.
33 Swinne D, Deppner M, Laroche R, et al. Isolation of Cryptococcus neoformans from house of AIDS-associated crypto-
coccosis patients in Bujumbura (Burundi). AIDS 1989;3: 389-90.

34 Saag MS, Powderly WG, Cloud GA, et al. Comparison of amphotericine B with fluconazole in the treatment of acute AIDS-associated cryptococcal meningitidis. N Engl F Med 1992;326:83-9.

35 Chuck SL, Sande MA. Infections with Cryptococcus neoformans in the acquired immunodefociency syndrome. N Engl f Med 1989;321:794-9.

36 van der Horst C, Saag MS, Cloud GA, et al. Treatment of cryptococcal meningitis associated with the acquired immunodeficiency syndrome. N Engl f Med 1997;337:1521.

37 Powderly WG, Saag MS, Cloud GA. A controlled trial of fluconazole or amphotericin B to prevent relapse of cryptococcal meningitis in patients with the acquired immunodeficiency syndrome. N Engl f Med 1992;326:793-8.

38 Porter SB, Sande MA. Toxoplasmosis of the central nervous system in the acquired immunodeficiency syndrome. $N$ system in the acquired imm
Engl f Med 1992;327:1643-8.

39 Luft BJ, Remington JS. Toxoplasmic encephalitis in AIDS. Clin Infect Dis 1992;15:211-22.

40 Richards FO, Kovacs JA, Luft B. Preventing toxoplasmic encephalitis in persons infected with human immunodeficiency virus. Clin Infect Dis 1995;21(supp 1):S49-S56.

41 Leport C, Raffi F, Matheron S, et al. Treatment of central nervous system toxoplasmosis with pyrimethamine/ sulfadiazine combination in 35 patients with the acquired immunodeficiency syndrome: efficacy of long term continuous therapy. Am F Med 1988;84:94-100.

42 Lane HC, Laughon BE, Falloon J, et al. Recent advance in the management of AIDS-related opportunistic infection. Ann Intern Med 1994;120:945-55.

43 Canessa A, Del Bono V, De Leo P, et al. Cotrimoxazole therapy of Toxoplasma gondii encephalitis in AIDS

44 Smadja D, Fournerie P, Cabre P, et al. Efficay and safety of cotrimoxazole as a treatment of toxoplasmic encephalitis in AIDS patients. Presse Med 1998;27:1315-20.

45 Murray CJ, Styblo K, Rouillon A. Tuberculosis in developing countries: burden, intervention and cost. Bull Int Union Tuberc Lung Dis 1990;65:6-24.

46 Hopewell PC. Impact of human immunodeficiency virus infection on the epidemiology, clinical feature, management, and control of tuberculosis. Clin Infect Dis 1992;15: 540-7.

47 Dolin PJ, Raviglione MC, Kochi A. Global tuberculosis incidence and mortality during 1990-2000. Bull World Health Organ 1994;72:213-20.

48 Shafer R, Edlin BR. Tuberculosis in patients infected with human immunodeficiency virus: perspective on the past decade. Clin Infect Dis 1996;22:683-704.

49 Berenguer J, Moreno S, Laguna F, et al. Tuberculous meningitis in patients infected with the human immunodeficiency virus. N Engl f Med 1992;326:668-72.

50 Small PM, Schecter GF, Goodman PC, et al. Treatment of tuberculosis in patients with advanced human immunodeficiency virus infection. N Engl f Med 1991;324:289-94.

51 Dube MP, Holtom PD, Larsen RA. Tuberculous meningitis in patients with and without human immunodeficiency virus infection. Am f Med 1992;93:520-4.

52 Greenberg AE, Nguyen-Dinh P, Mann JM, et al. The association between malaria, blood transfusion, and HIV seropositivity in a pediatric population. $7 A M A$ 1996;259: 545-9.

53 Lobato M, Caldwell B, Ng P, et al, and the Pediatric Spectrum of Disease Clinical Consortium. Encephalopathy in children with with perinatally acquired human immunodeficiency acquired infection. $\mathcal{F}$ Pediatr 1995;126:715.

54 Burns DK. The neuropathology of pediatric acquired immunodeficiency syndrome. F Child Neurol 1992;7:33246

55 Kure K, Llena JF, Lyman WD, et al. Human immunodeficiency virus-1 infection of the nervous system: an autopsy study of 268 adult, pediatric, and fetal brains. Hum Pathol 1991;22:700-10

56 Bell JE, Lowrie S, Koffi K, et al. The neuropathology of HIV-infected African children in Abidjan, Cote d'Ivoire. $\mathcal{F}$ Neuropathol Exp Neurol 1997;56:686-92.

57 Lambert $\mathrm{G}$, Thea D, Pliner V, et al. Effect of maternal CD4+ count acquired immunodeficiency syndrome, and viral load on disease progression in infants with perinatally acquired human immunodeficiency virus type 1 infection. F Pediatr 1997;130:897.

58 Park YD, Belman AL, Kim TS, et al. Stroke in pediatric acquired immunodeficiency syndrome. Ann Neurol 1990; 28:303-11.

59 Gelbard HA, Epstein LG. HIV-1 encephalopathy in children. Curr Opin Pediatr 1995;7:655-62

60 Floeter MK, Civitello LA, Everett CR, et al. Peripheral neuropathy in children with HIV infection. Neurology 1997;49:207-12.

61 Boivin MJ, Green SD, Davies AG, et al. A preliminary evaluation of the cognitive and motor effects of pediatric HIV infection in Zairian children. Health Psychol 1995;14: 13-21.

62 Drotar D, Olness K, Wiznitzer M, et al. Neurodevelopmental outcomes of Ugandan infants with human immunodeficiency virus type 1 infection. Pediatrics 1997;100:E5.

63 Lepage P, Hitimana D, van Goethem C, et al. Testing of children born to human immunodeficiency virus type 1 seropostive Msellati neurodevelopmental and seronegative 
mothers: a prospective cohort study in Kigali, Rwanda. Pediatrics 1993;92:843-8.

64 Montgomery RD, Cruickshank EK, Robertson WB, et al. Clinical and pathological observations on Jamaican neuropathy. Brain 1987;425:1964.

65 Gessain A, Barin F, Vernant JC, et al. Antibodies to human T lymphotropic virus type-1 in patients with tropical spastic paraparesis. Lancet 1985; ii:407-9.

66 Osame M, Usuku K, Izumo S, et al. HTLV-1 associated myelopathy, a new clinical entity. Lancet 1986;i:1301.

67 Gessain A, Gout O. Chronic myelopathy associated with human T-lymphotropic virus type 1 (HTLV-1). Ann Intern Med 1992;117:933.

68 Vernant JC, Maurs L, Gessain A, et al. Endemic tropical spastic paraparesis associated with human $\mathrm{T}$ lymphotropic virus type-1: a clinical and seroepidemiological study of 25 cases. Ann Neurol 1987;21:123.

69 Roman JC. The neuroepidemiology of tropical spastic paraparesis. Ann Neurol 1988;23(suppl):113.

70 Oresis. Ann Neurol 1988;23(suppl): 113 . myelopathy: an endemic disease of Canadian aboriginals of myelopathy: an endemic disease of Canadian aboriginals of the North

71 Rodgers-Johnson PE. Tropical spastic paraparesis/HTLV-1 associated myelopathy. Etiology and clinical spectrum. Mo Neurobiol 1994;8:175-9.

72 Krämer A, Maloney EM, Morgan O, et al. Risk factors and cofactors for human T-cell lymphotropic virus type 1 (HTLV-1)-associated myelopathy/tropical spastic para-
paresis (HAM/TSP) in Jamaica. Am F Epidemiol 1995;142: 1212-9.

73 Araujo A, Afonso CR, Schor, et al. Clinical and demographic features of HTLV-1 associated myelopathy/tropical spastic paraparesis (HAM/TSP) in Rio de Janeiro, Brazil. Acta Neurol Scand 1993;88:59-62.

74 Bhigjee AI, Kelbe C, Haribhai HC, et al. Myelopathy associated with human $\mathrm{T}$ cell lymphotropic virus type 1 (HTLV-1) in Natal, South Africa. A clinical and investigative study in 24 patients. Brain 1990;113:1307-20.

75 Kuroda Y, Yukitake M, Kurohara K, et al. A follow-up study on spastic paraparesis in Japanese HAM/TSP. F Neurol Sci on spastic parapare

76 Araujo AQ, Leite AC, Dultra SV, et al. Progression of neurological disability in HTLV-1-associated myelopathy tropical spastic paraparesis (HAM/TSP). I Neurol Sci 1995;129:147-51.

77 Bartholomew C, Cleghorn F, Jack N, et al. Human T-cell ymphotropic virus type 1-associated facial nerve palsy in Trinidad and Tobago. Ann Neurol 1997;41:806-9.

78 Smadja D, Bellance R, Cabre P, et al. Clinical characteristics of HTLV-1-associated dermato-polymyositis (seven cases from Martinique). Acta Neurol Scand 1995;92:206-12

79 Vernant JC, Buisson G, Magdeleine J, et al. T lymphocyte alveolitis, tropical spastic paraparesis, and Sjögren syn-
drome. Lancet 1988;i:177.

80 Merle H, Smadja D, Le Hoang P, et al. Ocular manifestations in patients with HTLV-1-associated infection (a clinical study of 93 cases). Fpn f Ophtalmol 1996;40:260-70.

81 Gessain A, Saal F, Gout, et al. High human T-cell lymphotropic virus type 1 proviral DNA load with polyclonamphotropic virus type 1 proviral DNA moadion in peripheral blood mononuclear cells of French West Indian, Guianese, and African patients with tropical spastic paraparesis. Blood 1990;75:428.

82 Gessain A, Caudie C, Gout O, et al. Intrathecal synthesis of antibodies to human lymphotropic virus type 1 and the presence of IgG oligoclonal bands in the cerebrospinal fluid of patients with endemic tropical spastic paraparesis. $\mathcal{F}$ Infect Disease 1988;157:1226.

83 Kitze B, Usuku K, Izumo S, et al. Diversity of intra-thecal antibody synthesis against HTLV-1 and its relation to HTLV-1 associated myelopathy. F Neurol 1996;243:393-
84 Moritoyo H, Arimura K, Arimura Y, et al. Study of lower limb somatosensory evoked potentiels in 96 cases of HAM/ TSP. F Neurol Sci 1996;138:78-81.

85 Godoy AJ, Kira J, Hasuo K, et al. Characterization of cerebral white matter lesions of HTLV-1-associated myelopathy/tropical spastic paraparesis in comparaison with multiple sclerosis and collagen-vasculitis: a semiquantitative MRI study. 7 Neurol Sci 1995;133: 102-11.

86 Umehara F, Izumo S, Nakagawa $\mathrm{M}$, et al. Immunocytochemical analysis of the cellular infiltrate in the spinal cord lesions in HTLV-1-associated myelopathy. 7 Neuropathol Exp Neurol 1993;52:424-30.

87 Tangy F, Vernant JC, Coscoy L, et al. A search for human T-cell leukemia virus type 1 in the lesions of patients with tropical spastic paraparesis and polymyositis. Ann Neurol 1995;38:454-60.

88 Kira J, Itohama Y, Koyanagi Y, et al. Presence of HTLV-1 proviral DNA in central nervous system of patients with HTLV-1 associated myelopathy. Ann Neurol 1992;31:3945.

89 Kuroda Y, Matsui M. Cerebrospinal fluid interferon- $\gamma$ is increased in HTLV-1-associated myelopathy. $\mathcal{F}$ Neuroimmunol 1993;42:223-6.

90 Umehara F, Izumo S, Ronquillo A, et al. Cytokine expression in the spinal cord lesions in HTLV-1-associated myelopathy. F Neuropathol Exp Neurol 1994;53:72-7.

91 Greten TF, Slansky JE, Kubota R, et al. Direct visualisation of antigen-specific T cells : HTLV-1 Tax 11-19-specific CD8(+) T cells are activated in peripheral blood and accumulate in cerebrospinal fluid from HAM/TSP patients. Proc Natl Acad Sci USA 1998;95:7568-73.

92 Lehky TJ, Fox CH, Koenig S, et al. Detection of human T-lymphotropic virus type 1 (HTLV-1) Tax RNA in the central nervous system of HTLV-1-associated myelopathy/ tropical spastic paraparesis patients by in situ hybridization. Ann Neurol 1995;37:167-75.

93 Moritoyo T, Reinhart T, Moritoyo H, et al. Human T-lymphotropic virus type 1 associated myelopathy and Tax gene expression in CD4+ T lymphocytes. Ann Neurol 1996;40:84-90.

94 Hollsberg P, Batra V, Dressel A, et al. Induction of anergy in CD $8 \mathrm{~T}$ cells by B cell presentation of antigen. F Immunol 1996;157:5269-76.

95 Umehara F, Nakamura A, Izumo S, et al. Apoptosis of T lymphocytes in the spinal cord lesions in HTLV-1associated myelopathy: a possible mechanism to control viral infection in the central nervous system. $\mathcal{F}$ Neuropathol Exp Neurol 1994;53:617-24.

96 Giraudon P, Vernant JC, Confavreux C, et al. Matrix metalloproteinase 9 (gelatinase B) in cerebrospinal fluid of HTLV-1 infected patients with tropical spastic paraparesis. Neurology 1998;50:1920.

97 Osame M, Matsumoto M, Usuku K, et al. Chronic progressive myelopathy associated with elevated antibodies to human T-lymphotropic virus type 1 and adult T-cell leukemia cells. Ann Neurol 1987;21:117-22.

98 Nakagawa M, Nakahara K, Maruyama Y, et al. Therapeutic trials in 200 patients with HTLV-1-associated myelopathy/ tropical spastic paraparesis. 7 Neurovirol 1996;2:345-55.

99 Kataoka A, Imai H, Inayoshi S, et al. Intermittent high-dose vitamin C therapy in patients with HTLV-1-associated myelopathy. F Neurol Neurosurg Psychiatry 1993;56:121316.

100 Hatae T, Hara H, Kobayashi T, et al. The effect of rolipram on the production of cytokines in HTLV-1 infected cell lines and peripheral blood mononuclear cells of patients with HTLV-1-associated myelopathy (HAM). f Neurol Sci 1997;148:87-9 